\title{
Analysis of Using Tools of Strategic Management in SMEs in South Bohemia Region
}

\author{
Monika Březinová ${ }^{1}$, Agnieszka Brelik $^{2}$, Vratislav Kozák ${ }^{3}$
}

\begin{abstract}
:
Strategic management plays an important role in making up the competitiveness of small and medium-sized enterprises. The aim of this article is to find how much SME includes principals and tools of the strategic management, especially how they are formulated strategy.

In the research project was used secondary data (financial statements of SMEs who took part in the research) and primary data which were obtained primarily through quantitative methods questionnaire supplemented by qualitative method of in-depth interviews.

Majority of examined small and medium enterprises had formulated strategy. They are aimed mainly at stability, further at quality, development and profit. The research is financed by: GAJU 068/2010/S, GAJU 039/2013/S, GAJU 079/2013/S
\end{abstract}

Keywords: management, enterprise, SME, strategy, stability, development, profit

JEL Classification: M12, M11

\footnotetext{
${ }^{1}$ University of South Bohemia in České Budějovice Faculty of Agriculture Landscape Management brezina@zf.jcu.cz

${ }^{2}$ West Pomerania University of Technology, Szczecin, Faculty of Economics, Department of European and Regional Studies Agnieszka.Brelik@ zut.edu.pl

${ }^{3}$ Tomáš Bat'a University in Zlín, Faculty of Management and Economy, Management and Marketingkozak@fame.utb.cz
} 


\section{Introduction}

SMEs are indispensable in all economies, can be described as a driving force of business, growth, innovation, competitiveness, and are also very important employers (Yanes-Estevez and Oreja-Rodriguez, 2014). In the Czech Republic in a research contacted in 2011 there were 1,066,787 legal and natural persons who were placed in the category of small and medium-sized enterprises. The total number of active small and medium-sized enterprises participated in this research was $99.84 \%$. The share of employees in small and medium-sized enterprises amounted to $60.85 \%$ in relation to the total number of employees in the Czech economy.

According to Macky and Pio, (2015) the small and medium-sized businesses will create and offer new and quality jobs. According to Pícha, Skořepa and Navrátil, (2013) management of small and medium-sized enterprise has many specifics. In small companies due to the small number of employees and managers many functions are accumulated within the competence of only a few workers predominates, informal leadership is more common, oral communication is preferred than written, etc. According to Lai, Saridakis, Blackburn and Johnstone, (2016) a high degree of flexibility to adapt rapidly the changing SME factors, it determines the face and reduce the growing globalization tendencies associated with the onset of multinational corporations and chains. But the principle of important role of strategic management comes here in the force too (Švarova and Vrchota, 2013). Strategic management, based on long-term forecasts, helps the company to anticipate future challenges and opportunities (Bateman, 2003; Dasanavaka et al., 2015).

According Medek, (2005) strategic management gives clear goals and directions for the future of the company and to its workers a sense of security. Strategic management helps to increase the quality of management, leads managers to improve their deciding. Chraif and Anitei, (2012) state that strategic management helps improve communication in the company, project coordination, staff motivation and improve resource allocation. The strategy is the basic tool to reach advantages in the market (Slabá, Štarchoň, Jáč, 2014). Holátová, Březinová and Kantnerová (2015) argued that the strategic management should be flexible to changed conditions in the market. Allen, (2016) declared that the management should have the strategic plan and strategy.

The management of enterprises of different size and specialization are today under the press of advantages, challenges and problems connected with the function of worldwide markets (Semenescu, 2013). The different meaning of the term of management can be related as follows: people who wish to have a career as a manager must study the discipline of management as a means toward practicing the process of management. The process consists of certain basic management functions (Andreeva and Sergeeva, 2016). Global competition carries with it an everincreasing set of demands by the customers. Better quality, more features, better delivery, performance and reduced costs - all become part of the expectation for our 
customers (Artieda, 2015). Strategic management is that set of managerial decisions and actions that determines the long run performance of a corporation (Wheelen and Hunger, 2008). Strategy can be viewed as building defenses against the competitive forces or as finding a position in an industry where the forces are weaker. Changes in the strength of the forces signal changes in the competitive landscape critical to ongoing strategy formulation in exploring the implications of the five forces framework (Nadanyiova and Kicova, 2015; Havlicek et al., 2013; Breckova and Havlicek, 2103).

Strakova et al. (2016) give two definitions of strategy, traditional and modern. Traditional definition approaches to understand the strategy of the company as a document in which there are long-term objectives of the company, determined the process of operations and allocation the resources needed to meet these goals. The modern concept sees strategy as the company prepared for the future. The strategy includes the long-term objectives of the company, the process of strategic operations and deployment of enterprise resources needed to meet these goals, so the strategies would be based on business needs, consider the changes in its resources and capabilities, and at the same time adequately respond to changes in the environment of the company. The central concept of strategic management is a strategy that is closely linked to the objectives it tracks. According to Gretzinger et al. (2014) strategies express the basic idea of which way the company goals will be achieved. There is no one best way to manage say Wheelen and Hunger (2008).

The British banker and financier Nathan Rothschild noted that great fortunes are made when cannonballs fall in the harbor, not when violins play in the ballroom. Rothschild understood that the more unpredictable the environment, the greater the opportunity if you have the leadership skills to capitalize on it say (Paul, Krupp, Howland, 2013; Ivanova et al., 2017). The article deals with the mapping of the fundamental characteristics of SMEs in terms of their strategic management.

\section{Methodology}

This article is provided as one of the outputs of the research project "Process management and the possibility of its implementation in small and medium-sized enterprises" of Grant Agency of the University of South Bohemia GAJU 068/2010/S and serves as one of the sources for grant GAJU 039/2013/S.

In the research project were used secondary data (financial statements of SMEs who took part in the research) and primary data which were obtained primarily through quantitative methods questionnaire supplemented by qualitative method of in-depth interviews.

For the classification of small and medium-sized enterprises it has been used a new definition of the European Union (European Commission: A new definition of SMEs 2006) in accordance with the Law No. 47/2002 Coll. as amended. This system has 
been adapted for the needs of the research, where the group of small businesses was divided into two groups according to the number of employees to achieve detailed breakdown.

Table 1: Classification of SMEs

\begin{tabular}{|l|l|l|l|}
\hline Enterprise size & $\begin{array}{l}\text { Number of } \\
\text { employees } \\
\text { (Annual Work Unit) }\end{array}$ & Annual turnover & $\begin{array}{l}\text { Annual balance } \\
\text { sheet }\end{array}$ \\
\hline Medium enterprise & $50-249$ & $<50$ mil. $€$ & $<50$ mil. $€$ \\
\hline \multirow{2}{*}{ Small enterprise } & $25-49$ & $<10$ mil. $€$ & $<10$ mil. $€$ \\
\cline { 2 - 4 } & $10-24$ & $<10$ mil. $€$ & $<10$ mil. $€$ \\
\hline Micro enterprise & $0-9$ & $<2$ mil. $€$ & $<2$ mil. $€$ \\
\hline
\end{tabular}

Source: European Commission: A new definition of SMEs 2006.

In the South Bohemian region in 2011 was registered 68,826 economic entities from the selected category. Enterprises with up to 9 employees (micro-enterprises) represent $18 \%$ of the total number. Small enterprises represent less than $4 \%$ of all the small and medium-sized enterprises in the region. There are registered $78 \%$ of medium-sized enterprises within the region (Statistical Bulletin- South Bohemian region, 2011).

According to the legal form of business in the basic aggregate there dominate private entrepreneurs $(77 \%)$, after that companies $(9 \%)$, associations $(5 \%)$, corporations of proprietors and cooperatives (3\%), foreign persons $(2.5 \%)$ and others (European Commission). Key figures on European business with a special feature on SMEs 2011.The prevailing business activities according to the classification of economic activities CZ-NACE in the examined aggregate constitutes wholesale and retail $(22 \%)$. Building industry and industry are represented within the research identically with $13 \%$, within the region there are about 21,000 or 19,000 and so they occupy the second and third position from the point of view of CZ-NACE.

Business activities according to CZ-NACE such as section A - agriculture, forestry and fishing, section B - mining and extraction and section I - accommodation, catering and restaurants, were eliminated from the research because of their different perception and management of company processes - these are completely specific groups. There was chosen a research sample from the base aggregate with the method of improbability of random choice because of difficult conditions of data collection.

The research sample consists of 187 small and medium-sized enterprises of South Bohemia region. Composition of the research sample according to size (number of employees) and activity is indicated in Tables 2 and 3. 
Table 2: Research Sample of Small and Medium-Sized Enterprises According to Number of Employees

\begin{tabular}{|l|l|l|}
\hline Number of employees & \multicolumn{2}{|l|}{ Number of enterprises } \\
\hline $0--9$ & 20 & $11 \%$ \\
\hline $10--24$ & 70 & $37 \%$ \\
\hline $25--49$ & 36 & $19 \%$ \\
\hline $50--249$ & 61 & $33 \%$ \\
\hline
\end{tabular}

Source: Own research.

Table 3: Research Sample of Small and Medium-sized Enterprises according to Business Activity

\begin{tabular}{|l|l|l|}
\hline Activity & \multicolumn{2}{|l|}{ Number of enterprises } \\
\hline Building industry & 51 & $27 \%$ \\
\hline Engineering & 57 & $30 \%$ \\
\hline Wood production & 22 & $12 \%$ \\
\hline Food production & 11 & $6 \%$ \\
\hline Trade & 22 & $12 \%$ \\
\hline Services and Transport & 24 & $13 \%$ \\
\hline
\end{tabular}

Source: Own research.

\section{Tools of Strategic Management in SMEs in South Bohemia Region}

From the point of view of categories due to number of employees is evident, that the majority (more than 60\%) of enterprises has a formulated strategy. Differences concerning strategies and their formulation at individual categories of examined small and medium-sized enterprises are indicated in Table 3.

At the medium-sized enterprises (with more than 50 employees) the frequency is about $87 \%$. It is surprising that $72 \%$ of micro-enterprises (up to 9 employees) also have formulated strategy. From the point of view of written formulation of the examined strategy the number of enterprises is lower, since the number logically grows with the enterprise size. Micro-enterprises have then written formulated strategy only in $9 \%$ of cases, on the contrary medium-sized enterprises in $63 \%$ of cases, at the same time where enterprises with more than 150 employees have written formulated strategy in $83 \%$ of cases. It is possible to compare the given results in Figure 1 where curves of frequencies of examined enterprises having the formulated strategy, and of enterprises having the strategy formulated in the written form, are obvious. 
Table 4: Frequencies of Formulated Strategies of Examined Small and Mediumsized Enterprises according to the Number of Employees

\begin{tabular}{|l|l|l|l|l|l|}
\hline \multirow{2}{*}{$\begin{array}{l}\text { Number of } \\
\text { employees }\end{array}$} & \multirow{2}{*}{$\begin{array}{l}\text { Number of } \\
\text { enterprises }\end{array}$} & Formulated strategy & Written formulated strategy \\
\cline { 2 - 6 } $0-9$ & 20 & $72 \%$ & no & yes & no \\
\hline $10-24$ & 70 & $61 \%$ & $28 \%$ & $9 \%$ & $81 \%$ \\
\hline $25-49$ & 36 & $69 \%$ & $39 \%$ & $30 \%$ & $70 \%$ \\
\hline $50-249$ & 61 & $87 \%$ & $31 \%$ & $61 \%$ & $39 \%$ \\
\hline
\end{tabular}

Source: Own research.

Figure 1: Curves of Frequencies of Examined Small and Medium-sized Enterprises Having Formulated Strategy According to the Number of Employees.

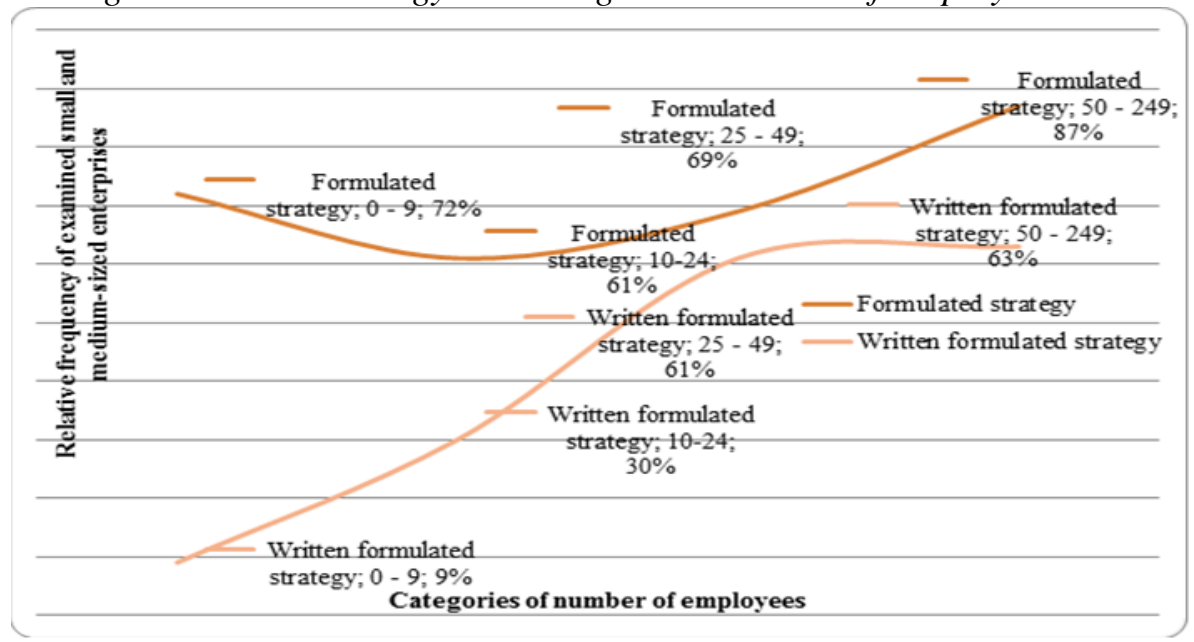

Source: Own research.

The formulation of strategy from the point of view of categories due to business activity is shown in the table 5. It is similarly for all enterprises, that always minimally $60 \%$ of them have formulated strategy. Most of the enterprises with formulated strategy are in the service sector $(81 \%)$, and with the written strategy $(59 \%)$. The enterprises in the sphere of commerce show a little bit lesser frequency, when $76 \%$ of them have formulated strategy and 44\% strategy in written form. Generally, enterprises in the field of production show the frequency about $74 \%$ in relation to the formulated strategy and $40 \%$ in relation to the written formulated strategy.

Strategies are most often created by enterprises which are concentrated on engineering production ( $81 \%, 49 \%$ written strategies). On the other side only $57 \%$ of enterprises which are focused on wooden production create strategies and only $14 \%$ of them have got a written version. Also, the construction enterprises focus on strategies less - only $63 \%$ of them prepare their strategies and only $39 \%$ out of the 
examined enterprises have written form. The data can be seen in Figure 2. The curves are basically copying the same line just with different values.

Table 5: Frequency of Examined SMEs with a Strategy according to Business Area

\begin{tabular}{|l|l|l|l|l|l|}
\hline \multirow{2}{*}{ Business area } & \multirow{2}{*}{$\begin{array}{l}\text { Number of } \\
\text { enterprises }\end{array}$} & Formulated strategy & \multicolumn{3}{|l|}{ Written formulated strategy } \\
\cline { 3 - 6 } & 51 & $63 \%$ & no & yes & no \\
\hline Construction & 51 & $81 \%$ & $37 \%$ & $39 \%$ & $61 \%$ \\
\hline $\begin{array}{l}\text { Engineering } \\
\text { production }\end{array}$ & 57 & $57 \%$ & $19 \%$ & $49 \%$ & $51 \%$ \\
\hline $\begin{array}{l}\text { Wooden } \\
\text { production }\end{array}$ & 22 & $75 \%$ & $43 \%$ & $14 \%$ & $86 \%$ \\
\hline $\begin{array}{l}\text { Food } \\
\text { production }\end{array}$ & 11 & $76 \%$ & $25 \%$ & $37 \%$ & $63 \%$ \\
\hline Trade & 22 & $81 \%$ & $24 \%$ & $44 \%$ & $56 \%$ \\
\hline $\begin{array}{l}\text { Services and } \\
\text { Transport }\end{array}$ & 24 & $19 \%$ & $59 \%$ & $41 \%$ \\
\hline
\end{tabular}

Source: Own research.

Figure 2: Curves of Frequency of Examined SMEs with a Strategy according to Business Area

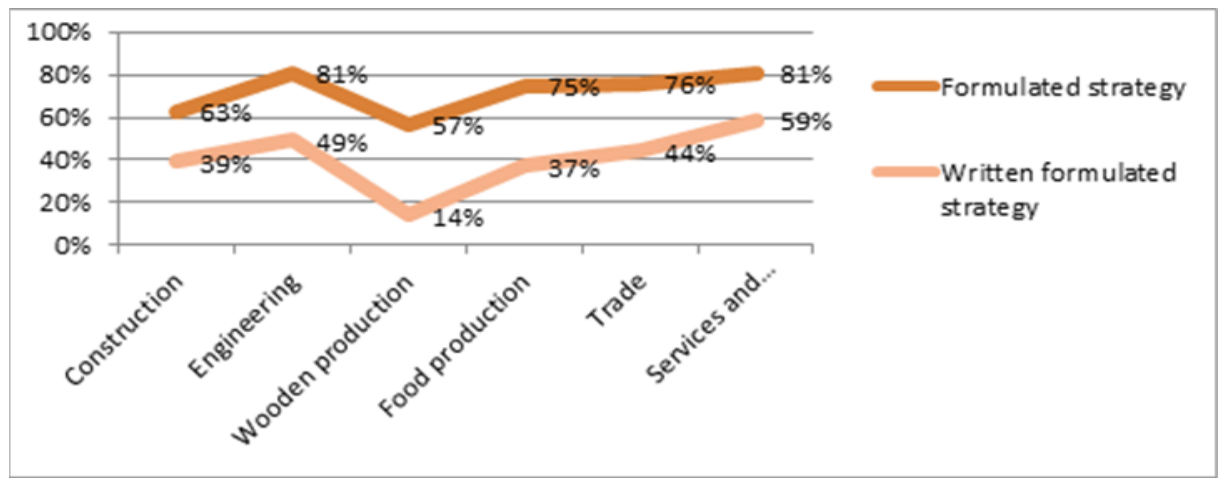

Source: Own research.

Out of 187 examined enterprises $31 \%$ of them didn't indicate their strategy type. The rest of the examined SMEs are focused on strategy of survival. Four categories were determined:

1) "Quality" (41\% of examined enterprises) - enterprises focus on quality in all aspects of business, on business ethics, they aim to have a good name, they are oriented on customers and make all the effort to satisfy them, these enterprises are working towards higher flexibility and reliability in everyday praxis and try to make their employees satisfied.

2) "Stability" (16\% of examined enterprises) - enterprises focus on stability within the market but also stabilization of its internal environment, for example 
keeping the same number of employees.

3) "Development" (8\% of examined enterprises) - enterprises focus on development of the enterprise in many areas - extension of production or provided services, market share and innovations.

4) "Profit" (4\% of examined enterprises) - enterprises focus on a long-standing growth of profit, this includes the growth of revenues and also decrease of costs.

Table 6 and Figure 3 shows the differences between strategies of SMEs from different categories. The strategies structure of examined enterprises is similar, similarity can also be seen in terms of order of relative frequencies. Categories differ in terms of followed strategies. Dominant strategy is "Quality" followed by 30\% of small enterprises (less than 50 employees), on the other side more than half (58\%) of enterprises with more than 50 employees follow this strategy. Second most common strategy is "Stability" around $20 \%$ of enterprises choose this strategy to reach their goals. "Development" strategy is followed by $10 \%$ of enterprises, but enterprises with more than 150 employees don't implement this strategy at all. Last strategy "Profit" is followed by $5 \%$ of enterprises.

Table 6: Frequency of Followed Strategies in examined SMEs according to the Number of Employees

\begin{tabular}{|l|l|l|l|l|l|l|}
\hline $\begin{array}{l}\text { Number of } \\
\text { employees }\end{array}$ & $\begin{array}{l}\text { Number } \\
\text { of } \\
\text { enterprises }\end{array}$ & Not specified & Quality & Stabilization & Development & Profit \\
\hline $0-9$ & 20 & $36 \%$ & $36 \%$ & $14 \%$ & $9 \%$ & $5 \%$ \\
\hline $10-24$ & 70 & $40 \%$ & $34 \%$ & $14 \%$ & $9 \%$ & $3 \%$ \\
\hline $25-49$ & 36 & $36 \%$ & $28 \%$ & $19 \%$ & $11 \%$ & $6 \%$ \\
\hline $50-249$ & 61 & $16 \%$ & $58 \%$ & $16 \%$ & $5 \%$ & $5 \%$ \\
\hline
\end{tabular}

Source: Own research.

Figure 3: Frequency of followed Strategies in examined SMEs according to the Number of Employees.

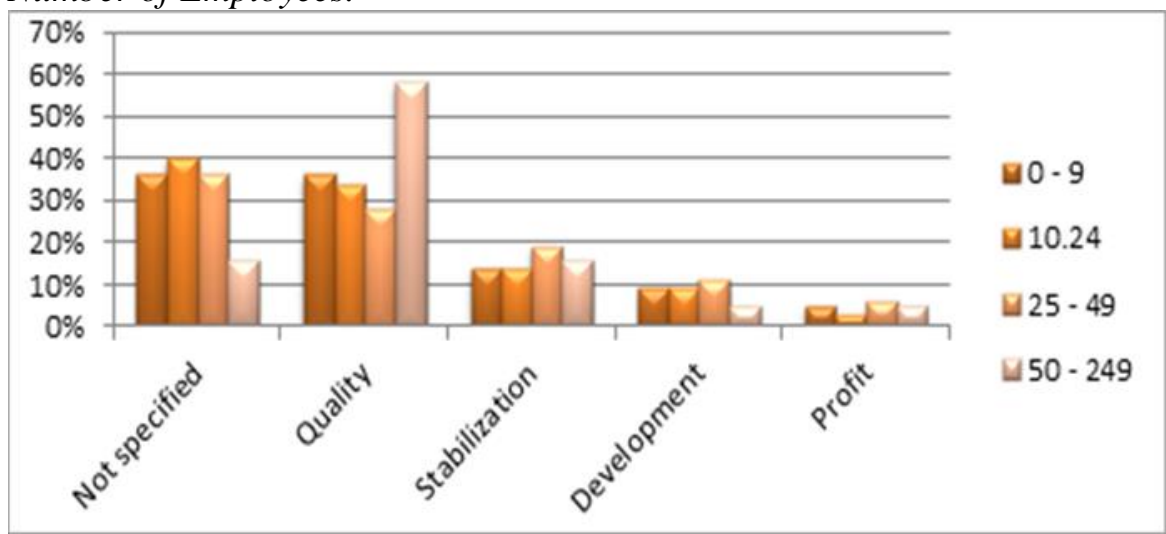

Source: Own research. 
Table 7 and Figure 4 highlight a similar analysis of SMEs presenting the results according to a business activity. The structure of implemented strategies is similar as above where the categories were created according to the number of employees, but some differences can be seen in order of relative frequencies. Enterprises working in construction usually follow "Quality" and "Stability" strategies, 9\% of enterprises follow "Profit" strategy and only 7\% follow "Development". Quality was the most followed strategy by manufacturing enterprises, even more dominantly as it was chosen by $40 \%$ businesses as the device to reach their goals. $17 \%$ manufacturing enterprises in total follow Stabilization strategy, roughly half less of them follow strategy focused on development, and just $2 \%$ of companies follow strategy of "Profit". Engineering production companies follow dominantly strategy of Quality, wood and food production companies follow strategy of Stabilization similarly. Most trading companies (Trade, 52\%) follow strategy of Quality, 20\% of companies are focused on strategy of Stabilization, just 4\% strive for fulfillment of Development. No trading company set profit strategy as its goal. Service companies follow mostly quality strategy (57\%), the second most frequent strategy was "Development". Just few service companies follow Profit (5\%) or Stabilization (3\%) strategy.

Table 7: Frequency of SME observed Strategies according to the Business Activity

\begin{tabular}{|l|l|l|l|l|l|l|}
\hline $\begin{array}{l}\text { Business } \\
\text { area }\end{array}$ & $\begin{array}{l}\text { Number of } \\
\text { enterprises }\end{array}$ & Not specified & Quality & Stabilization & Development & Profit \\
\hline Construction & 51 & $38 \%$ & $24 \%$ & $23 \%$ & $7 \%$ & $8 \%$ \\
\hline $\begin{array}{l}\text { Engineering } \\
\text { production }\end{array}$ & 57 & $36 \%$ & $41 \%$ & $10 \%$ & $11 \%$ & $2 \%$ \\
\hline $\begin{array}{l}\text { Wooden } \\
\text { production }\end{array}$ & 22 & $19 \%$ & $38 \%$ & $33 \%$ & $5 \%$ & $5 \%$ \\
\hline $\begin{array}{l}\text { Food } \\
\text { production }\end{array}$ & 11 & $37 \%$ & $38 \%$ & $25 \%$ & $0 \%$ & $0 \%$ \\
\hline Trade & 22 & $24 \%$ & $52 \%$ & $20 \%$ & $4 \%$ & $0 \%$ \\
\hline $\begin{array}{l}\text { Services and } \\
\text { Transport }\end{array}$ & 24 & $24 \%$ & $57 \%$ & $3 \%$ & $11 \%$ & $5 \%$ \\
\hline
\end{tabular}

Source: Own research.

Figure 4: Frequency of SME observed Strategies according to the Business Activity

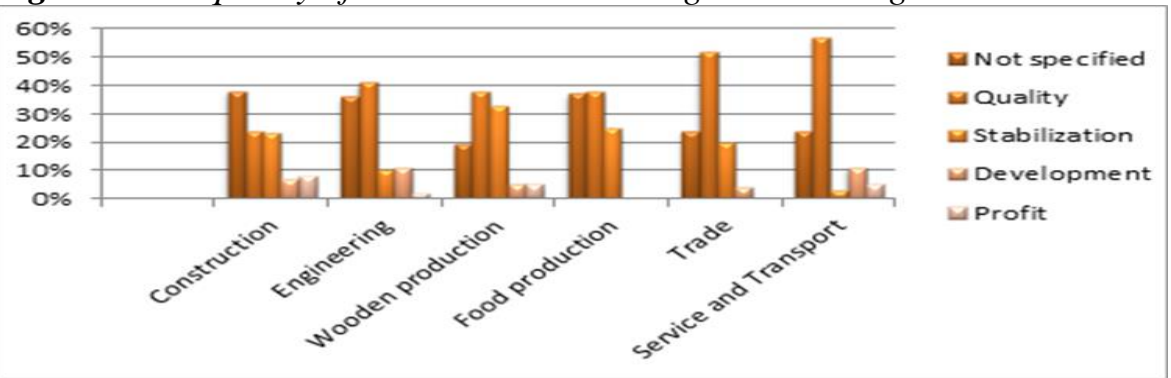

Source: Own research. 
Causal effects of strategy choice among observed small and medium enterprises according to the number of employee's category and the type of business activity were tested using statistical method of Kruskal-Wallis test. First, relation between strategy choice and number of employees was tested. Based on analyzed data we were able to confirm with $95 \%$ probability the null hypothesis that says there is no relation between tested variables $(H=6,675946 ; d f=4 ; p$-value $=0,1540)$.

Further, relation between strategy choice and category of business activity was tested. Based on analyzed data we were able to reject with $95 \%$ probability the null hypothesis in favor of the alternative hypothesis that says there is relation between examined variables $(H=7,849167$; $\mathrm{df}=3$; $\mathrm{p}$-value $=0,0492)$. This relation was tested using correlation coefficient $r$. Interdependence of strategy choice and business activity is evident in Table 8 and graphically in Figure 5. The strongest correlation $(80 \%)$ was detected by strategy choice of product engineering and trading companies. Strong correlation (74\%) was also found by determining strategy of building companies and wood processing companies. $68 \%$ correlation is visible by strategy choice of wood processing and service (transport included) companies. Last significant correlation, higher than $50 \%$, was discovered by wood processing and trading companies, building and service companies as transport included. On the other hand, no correlation was detected by determining strategy of production engineering and trading companies, food industry and trading companies.

Table 8: Correlation Coefficient of MSE Strategy according to the Business Activity

\begin{tabular}{|l|l|l|l|l|l|l|}
\hline & $\begin{array}{l}\text { Constructi } \\
\text { on }\end{array}$ & $\begin{array}{l}\text { Engineerin } \\
\text { g } \\
\text { production }\end{array}$ & $\begin{array}{l}\text { Wooden } \\
\text { productio } \\
\text { n }\end{array}$ & $\begin{array}{l}\text { Food } \\
\text { productio } \\
\text { n }\end{array}$ & Trade & $\begin{array}{l}\text { Services } \\
\text { and } \\
\text { Transport }\end{array}$ \\
\hline Construction & & 0,438736 & 0,741967 & $-0,102815$ & 0,808746 & 0,518120 \\
\hline $\begin{array}{l}\text { Engineering } \\
\text { production }\end{array}$ & 0,438736 & & 0,294688 & 0,022168 & 0,000000 & 0,319173 \\
\hline Wooden production & 0,741967 & 0,294688 & & $-0,146748$ & 0,543214 & 0,683588 \\
\hline Food production & $-0,102815$ & 0,022168 & $-0,146748$ & & 0,000000 & 0,345930 \\
\hline Trade and & 0,808746 & 0,000000 & 0,543214 & 0,000000 & & 0,147087 \\
\hline $\begin{array}{l}\text { Services } \\
\text { Transport }\end{array}$ & 0,518120 & 0,319173 & 0,683588 & 0,345930 & 0,147087 & \\
\hline
\end{tabular}

Source: Own research.

Pokorna,and Suchanek (2014) presented that majority of the small and medium sized companies has formally /as written document/ or not formally determined strategy. Presented research brought short term goals and brought also the similar results. Strategy has the goal to push forward the company towards to achieve short term goals and finally to achieve its basic purpose. The goals of the small and medium sized companies are often based on personal goals and preferences of the owners. Determined goals in such a way are logically very subjective, they are often not chosen correctly in comparison with the milieu where the companies create activities. 
Figure 5: Correlation Coefficient of MSE Strategy according to the Business Activity

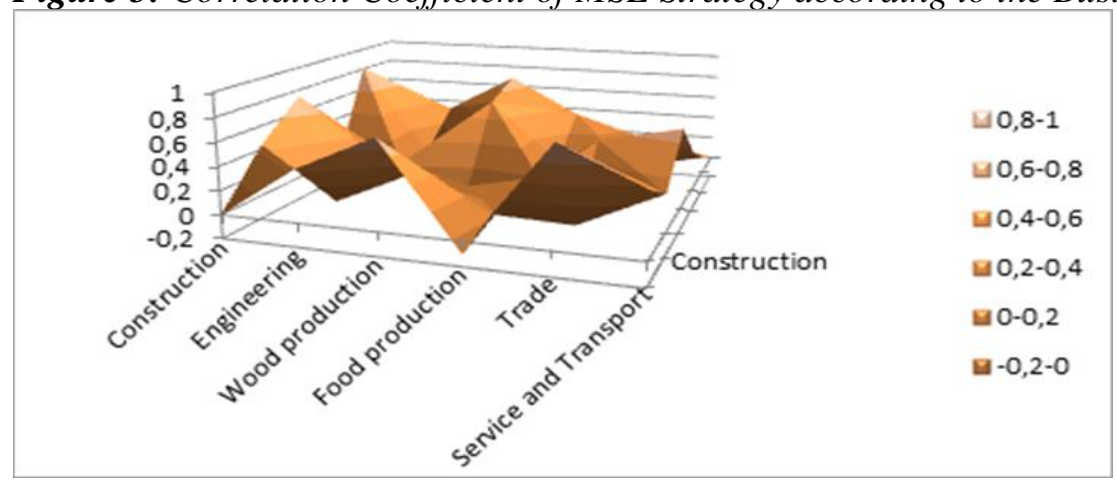

Source: Own research.

The goal of the company should always correspond with the chosen mission and should put into respect strong and weak aspects of undertaking, opportunities and distress, which the company can use or must face them. In general, the goal of the company should answer the basic questions of undertaking and present requested result. Target of any company consists from different aims; which management wants to reach, and which should be guaranteed by performance of different activities. These targets should be ambitious, easy to accomplish, quantifiable.

In the research sample of the small and medium sized companies in the frame of research there were identified 6 categories of the company goals. The category "Quality" was dominant. The companies presented for their goal both satisfaction of the customers (also employees) increasing the quality, good name of the company and flexibility. Following most often presented goal was "Development", the development of the whole company and separate development of the partial parts too. Innovation was also presented as the main goal in this category. Category "Stability" has also very strong representation, the companies presented the whole stability at the market and also stability of prices. In this category the companies also mentioned keeping the number of employees. Another goal relates to this matter and it is covering the market and Survival, which was followed in minimum cases. Concerning studying small and medium sized companies the goal Profit was, of course, dominant one.

In Table 9 and Figure 6 numerousness of searching of the goals of some small and medium sized companies according to the number of employees is presented. Following characteristics can be seen from these results. Concerning micro companies, the goals are concentrated on "Quality" (64\%), further "Development" $(50 \%)$, and "Stability" $(41 \%)$ on the contrary, no company follows the goal "Survival". The small companies to 24 employees follow the goal Stability in $57 \%$ of cases. In the small companies with more than 25 employees the main goals were "Quality", "Development" and "Stability" (55\%). These companies (the same as micro companies) do not follow the goal "Survival", in comparison with the small 
companies to 24 employees, that follow this goal, but only in $4 \%$. The medium sized companies follow in a dominant way the goal "Profit" (55\%), the second most often followed category is "Development" (46\%). 43\% medium sized companies follow the goal "Stability" and 34\% the goal "Quality". Minimum medium sized companies follow the goal "Survival" and "Covering" the market.

Table 9: Numerousness of the studying Goals of searched MSP according to the Number of Employees

\begin{tabular}{|c|c|c|c|c|c|c|c|}
\hline \multirow{2}{*}{$\begin{array}{l}\text { Number } \\
\text { of } \\
\text { employees }\end{array}$} & \multirow{2}{*}{$\begin{array}{l}\text { Number } \\
\text { of } \\
\text { comp. }\end{array}$} & \multicolumn{6}{|l|}{ Goal } \\
\hline & & Quality & $\begin{array}{l}\text { Covering of } \\
\text { market }\end{array}$ & Survival & Development & Stability & Profit \\
\hline $0-9$ & 20 & $64 \%$ & $18 \%$ & $0 \%$ & $50 \%$ & $41 \%$ & $32 \%$ \\
\hline $10-24$ & 69 & $43 \%$ & $4 \%$ & $6 \%$ & $32 \%$ & $57 \%$ & $40 \%$ \\
\hline $25-49$ & 35 & $55 \%$ & $8 \%$ & $0 \%$ & $55 \%$ & $55 \%$ & $33 \%$ \\
\hline $50-249$ & 60 & $34 \%$ & $8 \%$ & $8 \%$ & $46 \%$ & $43 \%$ & $51 \%$ \\
\hline
\end{tabular}

Source: Own research.

Figure 6: Numerousness of the studying Goals searching MSP according to the Number Employees.

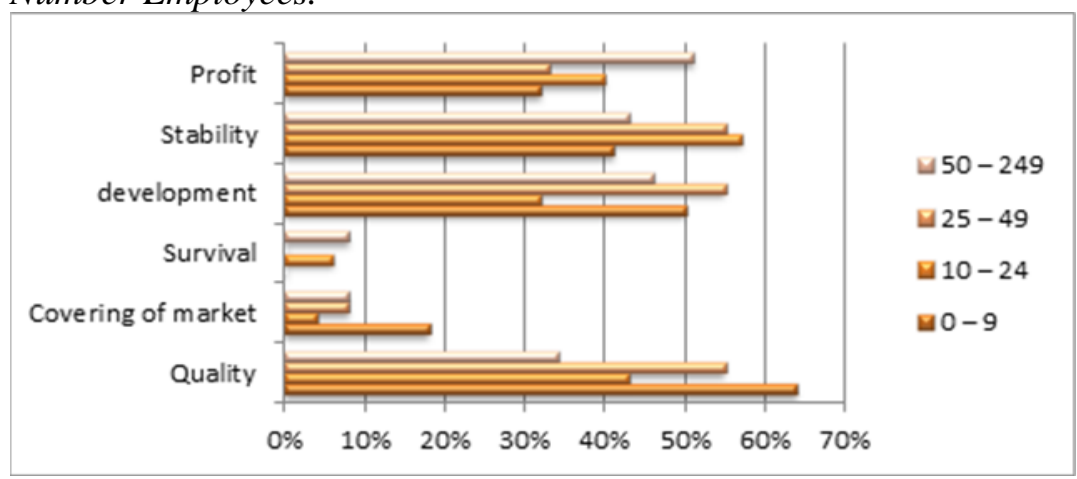

Source: Own research.

Table 10 and Figure 7 show numerousness concerning diversity according to the activity of the studying small and medium sized companies. Six categories of goals were analyzed here. Category Quality is dominant in business companies (72\%). Also, less than 50\% companies follow this goal in engineering production, on the contrary, food companies follow this goal minimum 18\%, this group follows mainly category Stability in $73 \%$ of cases. Companies in construction and wood follow the goal very strongly. Business companies follow this goal very rarely. Following the goal in the category of Covering the market was minimum in all studying activities of research of small and medium sized companies. Companies working in services including transport follow this goal in $15 \%$ and companies in engineering production follow this goal by $4 \%$. The goal Survival is minimum followed, food companies and business companies do not follow this goal at all. The 
rest of the companies shows only $5 \%$ to $7 \%$. In total $60 \%$ small and medium sized companies in engineering production follow the goal Development, $48 \%$ in services including transport and $38 \%$ wood working companies. Construction companies follow this goal with a minimum $27 \%$. The goal Profit is strongly dominant for no category of the companies. This goal is followed by $55 \%$ construction companies, $43 \%$ woodworking companies, $42 \%$ companies in services. Food companies follow this goal only by $18 \%$.

Table 10: Numerousness of the Goals examined MPS according to the activities.

\begin{tabular}{|l|l|l|l|l|l|l|l|}
\hline \multirow{2}{*}{ Business area } & \multirow{2}{*}{$\begin{array}{l}\text { Number } \\
\text { of comp. }\end{array}$} & \multicolumn{6}{l}{ Goal } \\
\cline { 3 - 9 } & & Quality & $\begin{array}{l}\text { Covering of } \\
\text { market }\end{array}$ & Survival & Development & Stability & Profit \\
\hline Construction & 50 & $40 \%$ & $7 \%$ & $7 \%$ & $27 \%$ & $62 \%$ & $55 \%$ \\
\hline $\begin{array}{l}\text { Engineering } \\
\text { production }\end{array}$ & 57 & $49 \%$ & $4 \%$ & $7 \%$ & $60 \%$ & $38 \%$ & $36 \%$ \\
\hline $\begin{array}{l}\text { Wooden } \\
\text { production }\end{array}$ & 22 & $29 \%$ & $5 \%$ & $5 \%$ & $38 \%$ & $71 \%$ & $43 \%$ \\
\hline Food production & 11 & $18 \%$ & $9 \%$ & $0 \%$ & $36 \%$ & $73 \%$ & $18 \%$ \\
\hline Trade & 21 & $72 \%$ & $12 \%$ & $0 \%$ & $36 \%$ & $28 \%$ & $36 \%$ \\
\hline $\begin{array}{l}\text { Services } \\
\text { Transport }\end{array}$ & 23 & $36 \%$ & $15 \%$ & $3 \%$ & $48 \%$ & $42 \%$ & $42 \%$ \\
\hline
\end{tabular}

Source: Own research.

Figure 7: Numerousness of studying Goals examined MPS according to the activities

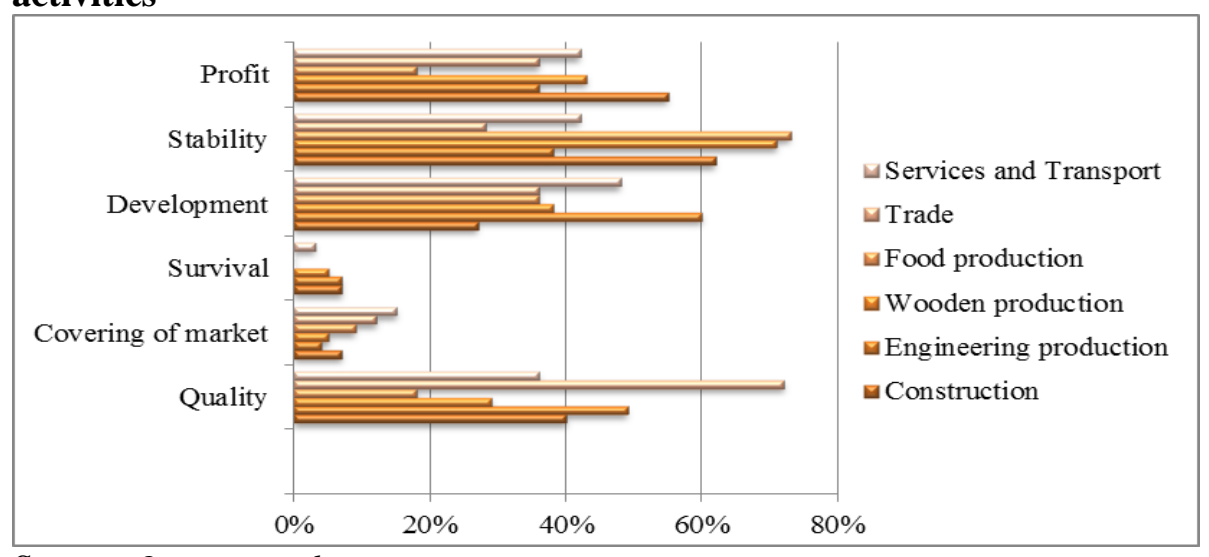

Source: Own research.

\section{Conclusions}

Majority of examined small and medium enterprises had formulated strategy, however, most enterprises with more than 25 employees has also a written version. From the business activity point of view is distinctly a lower frequency of 
formulated strategy by wood processing companies, strategy is formulated and put down in words most often by trading and service (transport included) enterprises. Based on tested data the most frequent followed strategy is quality and stabilization, regardless of employees' number category or business activity.

In the case where the company has determined goal, it is aimed mainly at Stability, further at Quality, Development and Profit. Small companies follow more Quality and Development, but medium sized companies follow mainly Development and Profit. Examined small and medium sized companies consider their strong pages mainly Range and Quality of work and on the contrary as threat Insolvency.

\section{References:}

Allen, J.E. 2016. Do We Need HR? Repositioning People Management for Success. Personal Review, 45(3), 616-618, DOI: 10.1108/PR-09-2015-0239.

Andreeva, T., Sergeeva, A. 2016. The more the better ... or is it? The contradictory effects of HR practices on knowledge-sharing motivation and behaviour. Human Resource Management Journal, 26(2), 151-171, DOI: 10.1111/1748-8583.121001.

Artieda, C. 2015. Analysis of cost systems as a strategic management tool for small and medium enterprises (SMEs) Revista Publicando, 2(3), 90-113.

Bateman, T. 2003. Thinking about Corporate Social Responsibility. Available from: www.transparency.cz/pdf/csr-thinking.pdf.

Břečková, P. and Havlíček, K. 2013. Leaders Management and Personnel Controlling in SMEs. European Research Studies Journal, 16 (4), Special Issue on SMEs.

Chraif, M., Anitei, M. 2012. A method of personnel fluctuation calculation for an interior design company from Romania. 3rd World Conference on Psychology, Counselling and Guidance (WCPCG). Efes, Turkey, Book Series Procedia Social and Behavioral Sciences, 84, 1021-1030.

Dasanayaka, S.W.S.B. and Sardana, D.G. 2015. Development of Small and Medium Enterprises through Clusters and Networking: A Comparative Study of India, Pakistan and Sri Lanka. International Journal of Economics and Business Administration, 3(2), 84-108.

Gretzinger, S., Lemke, S., Matiaske, W. 2014. Managing Human Resource Based Intellectual Capital in a Global Setting: The Impact of Cultural Practices on the Effectiveness of Retention Incentives. 11th International Conference on Intellectual Capital, Knowledge Management and Organisational Learning (ICICKM), University of Sydney Business School Sydney, 194-203, WOS:000351506700022.

Havlíček, K., Thalassinos. I.E. and Berezkinova, L. 2013. Innovation Management and Controlling in SMEs. European Research Studies Journal, 16(4), 57-70, Special Issue on SMEs.

Holátová, D., Březinová, M., Kantnerová, L. 2015. Strategic management of small and medium-sized enterprises. Source of the Document WSEAS Transactions on Business and Economics, 12(7), 65-73.

Ioana, A., Semenescu, A. 2013. Technological, Economic, and Environmental Optimization of Aluminum Recycling. Journal of the Minerals, Metals \& Materials Society, 65(8), 951-957.

Ivanova, A.E., Mackaev, M.M., Platonova, K.T., Elagina, V.N. 2017. Theoretical Basis for Composition of Economic Strategy for Industry Development. European 
Research Studies Journal, 20(1), 246-256.

Lai, Y.Q., Saridakis, G., Blackburn, R., Johnstone, S. 2016. Are the HR responses of small firms different from large firms in times of recession? Journal of Business Venturing, 31(1), 113-131, DOI: 10.1016/j.jbusvent.

Lo, K., Macky, K., Pio, E. 2015. The HR competency requirements for strategic and functional HR practitioners. International Journal of Human Resource Management, 26(18), 2308-2328, DOI: 10.1080/09585192.2015.1021827.

Medek, M. 2005. Internal and External Communication Like Necessary Factor of Survival. E + M Ekonomie a Management / E+M Economics \& Management, 8(2), 98-105.

Nadanyiova, M., Kicova, E. 2015. The Importance of Marketing Strategy as a Tool of the Strategic Management in the Bus Transport Companies. 19th International Scientific Conference on Transport Means. Kaunas Univ Technol, Kaunas, Book Series Transport Means - Proceedings of the International Conference, 717-720.

Krupp, P.H. 2013.Strategic Leadership:Esential Skills. Available at http://web.ebscohost.com/ehost/pdfviewer/pdfviewer?vid=5asid=089eb7c9-fcea4f4c-8dc9-2f3ac8b9e8e7\%40sessionmgr114ahid=120.

Perez, Yanes-Estevez, Oreja-Rodriguez, 2014. Strategic reference points, risk and strategic chosen in SMEs. Journal of Business Economic and Management, 15(3), 562-576.

Pokorna, .J., Suchanek, P. 2014. The Impact of Strategic Management Tools on Product Quality and Business Performance. International Multidisciplinary Scientific Conferences on Social Sciences and Arts. Albena, Bulgaria, Political Sciences, Law, Finance, Economics and Tourism. Book Series International Multidisciplinary Scientific Conferences on Social Sciences and Arts, 327-334.

Pícha, K., Skořepa, L., Navrátil, J. 2013. Assessment of the results of the strategic orientation on regional and local products in food retail. Acta Universitatis Agriculturae et Silviculturae Mendelianae Brunensis 61(4), 1061-1068.

Slabá, M., Štarchoň, P., Jáč, I. 2014. Identification and prioritization of key stakeholder groups in marketing communication of colleges. E \& M Ekonomie a management, 17(4), 101-110.

Švarova, M., Vrchota, J. 2013. Strategic management in micro, small and medium-sized businesses in relation to financial success of the enterprise. Acta Universitatis Agriculturae et Silviculturae Mendelianae Brunensis, 61(7), 2859-2866.

Wheelen, T.L., Hunger, J.D. 2008. Strategic management of intellectual property. http://web.ebscohost.com/ehost/pdfviewer/pdfviewer?vid=3\&sid=089eb7c9-fcea4f4c-8dc9-2f3ac8b9e8e7\%40sessionmgr114\&hid=120. 